\title{
Effectiveness of Curing Compound on Concrete
}

\author{
Dinesh W.Gawatre ${ }^{1}$, Komal Sawant ${ }^{2,}$ Rupali Mule ${ }^{2,}$ Neha Waydande ${ }^{2,}$ \\ Dhanashri Randeve ${ }^{2}$, Trupti Shirsath ${ }^{2}$. \\ ${ }^{\text {I }}$ Asst professor, Department of civil Engineering, Sinhgad Academy of Engineering, Pune-48. M.S., India) \\ ${ }^{2}$ (U.G. Student Department of civil Engineering, Sinhgad Academy of Engineering, Pune-48. M.S., India))
}

\begin{abstract}
In construction industries concerte are basic requirement to built any construction. Concrete is manmade material which is used all over the world. Curing is the most important factor of the concrete to perform planned functions throughout designed life of structure while immoderate curing time may intensify the construction cost of project and irrelevant delay of project, where there is deficiency of water and on downhill surfaces where curing with water is problematic and in cases where large areas like pavement have to be cured. As stated earlier about the conventional curing methods the use of membrane curing compounds is very important from the frame of reference that water resources are getting precious every day. The upgrading in the construction and chemical industries have lead the way for development of new curing techniques and construction chemicals such as Membrane curing compounds, Self curing agents, Water proofing compounds. In this paper we will compare results of different grade of concrete and curing compounds with various climatic changes.
\end{abstract}

Keywords: Curing, Grade of concrete, Membran curing Compound

\section{Introduction}

Curing is the name given to the procedures used for stimulating the hydration of the cement and consisting of control of temperature and of moisture movement from and into concrete. Curing is also a key player in relieving cracks in concrete, which severely influences durability. Proper curing can help mitigate the appearance of unplanned cracking and increases durability, strength, volume stability, abrasion resistance, impermeability and resistance to freezing and thawing. Curing allows continuous hydration of cement which is directly proportional to the continuous gain in the strength, once curing stops strength gain of the concrete also stop. With insufficient water, the hydration will not take place and the resulting concrete may not get the expected strength and impermeability.

\section{Methods And Material}

2.1. Curing Methods-

2.1.1. Dry curing method

2.1.2. Wet curing method

2.1.3. Steam curing method

2.1.4. Water retaining method:

2.1.1 Dry curing:

It is the process of curing in which no form of active curing by just uncovering the specimen in open atmosphere. Dry curing is inadequate method to achieve good hardened properties of concrete.

2.1.2Wet curing: It is also called as conventional curing technique because it is used since past. In this method the moisture loss can be prevented by regularly wetting the exposed surface of concrete, this in turn maintains the quality of water in the concrete.

\subsubsection{Ponding:}

It is a curing method where flat concrete surfaces such as slabs and pavements and cure by making small ponds of water around the perimeter of the surface with the help of sand dikes.

\subsubsection{Sprinkling:}

It is the type of wet curing in which water is sprinkled over the surface of concrete through a system of sprayer. It requires large amount of water. Water is spread on concrete in suitable interval.

\subsubsection{Wet covering:}

Wet covering is the method in which moisture conserving fabrics such as gunny bags and rugs are used as wet covering to keep the concrete in great condition. 


\subsubsection{Steam curing:}

It is the process of gaining high early strength under high atmospheric pressure and temperature $\left(40{ }^{\circ} \mathrm{C}\right.$ and $215^{\circ} \mathrm{C}$ ).It is mostly used for Pre -caste concrete members.

Cement:

\section{Material}

Cement (kumar cement) 53grade has been used for mix proportion of M50 and M20 grade of concrete.

Aggregate:

Two size aggregates are used $20 \mathrm{~mm}$ and $10 \mathrm{~mm}$ size.

Artificial sand:

In Pune region artificial sand will be used in study.

GGBS: Ground granulated blast-furnace slag. Physical of GGBS: Fineness modulus-3.35, specific gravity -3.44 . Chemical composition: carbon(C) $0.23 \%$, iron $(\mathrm{Fe}) 93.83 \%$, Silica $5.37 \%$.

\section{Curing compounds:}

Curing compounds are mainly used in membrane curing .They are available in following types Water based, Wax based ,Resin solvent based, Chlorinated rubber etc .Curing compounds are available in liquid as well as powder form. Curing compounds are applied on concrete by rollers, sprays, brushes etc. After application of curing compound on fresh concrete surface they form moisture conserved film .Curing compounds are applied on concrete at single coats and double coat. The application of coats of curing compounds removed the exposed concrete surface should be wetted with water immediately and kept moist until the curing compounds are applied.

\section{Uses of curing compound:}

Curing compound can be used with advantages where wet curing is impossible .It is suitable for areas of directly exposed to sunlight, heavy winds and other environmental influences. It can be used for curing concrete pavements, airport runway, and bridge deck.

Used for curing of: Concrete pavements, airport runway, bridge decks

- Precast concrete components

- Roof slabs, columns and beams.

- Chimneys, cooling towers and high rise structures.

Testing of curing compounds:

The curing compounds should be tested in accordance to ASTM:

Water retention - The Test should be conducted in accordance with test method C156. Reflectance Determine the daylight reflectance of white -pigmented compound in accordance with test methods E97

Drying time -The test should be conducted in accordance to ASTM C 309 clause 10.3

\section{MATERKURE 106:}

Masterkure 106 is the solvent free, membrane forming wax emulsion, suitable for spray application to freshly poured concrete. The resultant films retains sufficient moisture in the concrete to ensure full hydration of cement.

Table No 1: Typical Properties

\begin{tabular}{|l|l|}
\hline Appearance & White liquid \\
\hline Specific Gravity & 1.00 \\
\hline Flashpoint & Not applicable \\
\hline Finished film appearance & $\begin{array}{l}\text { Clear, tack free, Water } \\
\text { repellent film }\end{array}$ \\
\hline Water retention ASTM C156 & Pass \\
\hline Drying time ASTM C309 & Less than 4hours \\
\hline
\end{tabular}

Specification And Clause:

Concrete shall be cured by application of masterkure106, membrane forming wax emulsion manufactured by BASF or similar approved; to the following specification:

Specification type:

ASTM C 309: Type 1 Class A

AASHTO M-148. 


\section{Result}

TABLE NO 2: 3 days compressive strength for M50 grade of concrete

\begin{tabular}{|l|l|l|}
\hline $\begin{array}{l}\% \text { of } \\
\text { GGBS }\end{array}$ & $\begin{array}{l}\text { CONVENTIONAL } \\
\text { CURING(N/mm }{ }^{2}\end{array}$ & $\begin{array}{l}\text { MEMBRANE } \\
\text { CURING(N/mm }\end{array}$ \\
\hline 10 & 16.28 & 13.7 \\
\hline 20 & 19.04 & 17.2 \\
\hline 30 & 22.22 & 19.07 \\
\hline 40 & 24.00 & 20.50 \\
\hline 50 & 27.70 & 24.80 \\
\hline 60 & 27.9 & 26.89 \\
\hline
\end{tabular}

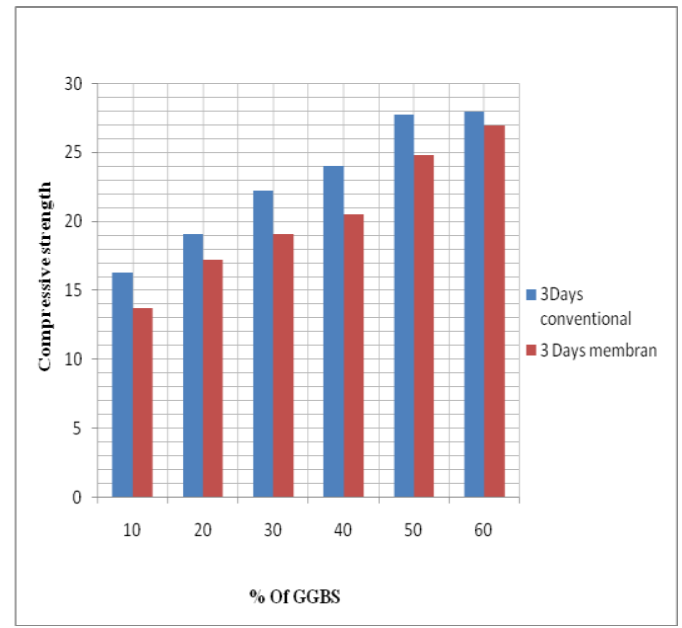

TABLE NO 3: 7 days compressive strength for M50 grade of concrete

\begin{tabular}{|l|l|l|}
\hline $\begin{array}{l}\% \text { of } \\
\text { GGBS }\end{array}$ & $\begin{array}{l}\text { CONVENTIONAL } \\
\left.\text { CURING(N/mm }{ }^{2}\right)\end{array}$ & $\left.\begin{array}{l}\text { MEMBRANE } \\
\text { CURING(N/mm }\end{array}{ }^{2}\right)$ \\
\hline 10 & 36.66 & 27.44 \\
\hline 20 & 40.77 & 33.78 \\
\hline 30 & 41.8 & 38.37 \\
\hline 40 & 49.57 & 40.07 \\
\hline 50 & 52.0 & 43.87 \\
\hline 60 & 56.79 & 49.78 \\
\hline
\end{tabular}

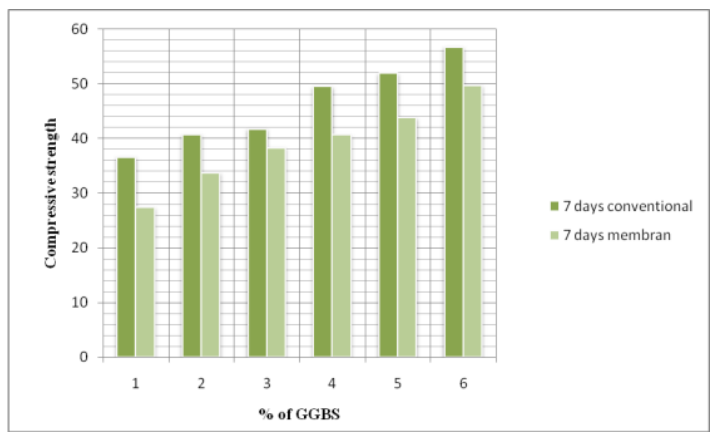

TABLE NO 4:28 days compressive strength for M50 grade of concrete

\begin{tabular}{|l|l|l|}
\hline $\begin{array}{l}\% \\
\text { GGBS }\end{array}$ & $\begin{array}{l}\text { CONVENTIONAL } \\
\left.\text { CURING(N/mm }{ }^{2}\right)\end{array}$ & $\begin{array}{l}\text { MEMBRANE } \\
\text { CURING(N/mm }\end{array}$ \\
\hline 10 & 58.25 & 50.00 \\
\hline 20 & 62.20 & 54.25 \\
\hline 30 & 67.50 & 59.06 \\
\hline 40 & 71.70 & 61.28 \\
\hline 50 & 79.07 & 67.90 \\
\hline 60 & 81.81 & 74.87 \\
\hline
\end{tabular}




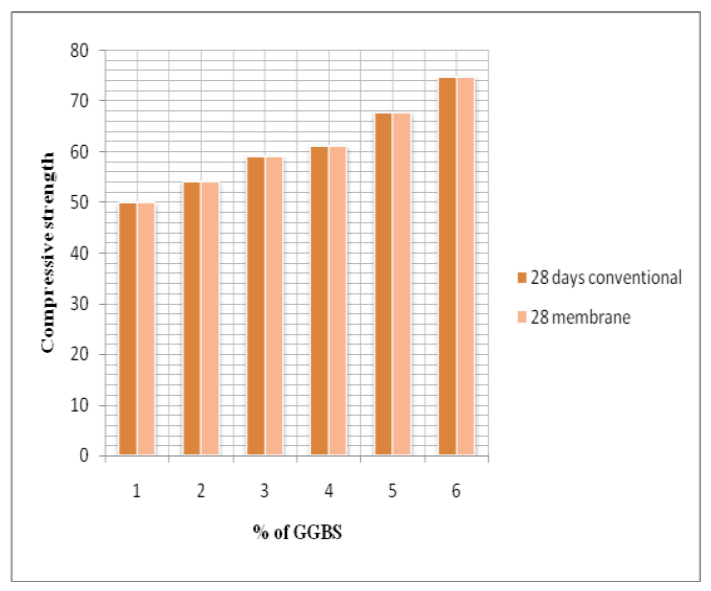

Table 5: Observation table of workability M20 and M50 grade of concrete with superpasticiser

\begin{tabular}{|l|l|l|l|}
\hline Sr No & $\begin{array}{l}\text { Percentage of } \\
\text { GGBS }\end{array}$ & $\begin{array}{l}\text { M 20 grade } \\
\text { slump value }\end{array}$ & M 20 grade slump value \\
\hline 1 & 10 & 31 & 70 \\
\hline 2 & 20 & 34 & 72 \\
\hline 3 & 30 & 38 & 73 \\
\hline 4 & 40 & 41 & 75 \\
\hline 5 & 50 & 43 & 78 \\
\hline 6 & 60 & 45 & 82 \\
\hline
\end{tabular}

\section{Conclusion}

1. After experimental study we are concluding that the strength of membrane curing is not efficient as compared to conventional curing by using GGBS .

2. By using membrane curing method strength will not gain properly by using GGBS

3. we are also observed that by using conventional method, increased percentage of GGBS strength will increased but by membrane curing not gain properly.

\section{Reference}

[1] Dr. K.V.Krishna Reddy. " A Comparative Study on Methods of Curing Concrete -Influence of Humidity."( ISSN: 2248-9622 Vol. 3, Issue 3, May-Jun 2013, pp.1161-1165 )International Journal of Engineering Research and Applications.

[2] 2. Kholia et al., PROF. Nirav R Kholia. studies of "effect on concrete by different curing method and efficiency of curing compounds " (International Journal of Advanced Engineering Technology E-ISSN 0976-3945)

[3] Akeem Ayinde Raheem, Aliu Adebayo Soyingbe, Amaka John Emenike studied "Effect of Curing Methods on Density and Compressive Strength of". (International Journal of Applied Science and Technology Vol. 3 No. 4; April 2013).

[4] M. Criado, A. Palomo, A. Ferna'ndez-Jime' "Studied Alkali activation of fly ashes. Part 1: Effect of curing conditions on the carbonation of the reaction products." (Eduardo Torroja Institute (CSIC), 28080)

[5] Houssam A. Toutanji , Ziad Bayasi. I studied "Effect of curing procedures on properties of silica fume(Cement and Concrete Research 29 (1999) 497-501)

[6] Pietro Lura, Klaas van Breugel2 and Ippei .studied "Effect of curing temperature and type of cement early-age shrinkage of High Performance Concrete Manufactured". (Cement and Concrete Research 31 (2001) 1867)

[7] M.V. Krishna Rao1, P. Rathish Kumar2*, Azhar M. Khan studied "A STUDY ON THE INFLUENCE OF CURING ON THE STRENGTH OF A STANDARD GRADE CONCRETE”.( Vol. 8, No 1, 2010, pp. 23 - 34 DOI: 10.2298/)

[8] G. Kovalchuk a, A. Ferna'ndez-Jime'nez b, A. Palomo studied "lkali-activated fly ash: Effect of thermal curing condit ions on mechanical and microstructural development - Part2". (Fuel 86 (2007) 315-322ISSN 2320-0847, Vol. 02, Issue-12, 2013)

[9] IS459-2000 (Plain and reinforced concrete)

[10] IS10262-2012 (Guidelines for concrete mix design proportioning)

[11] IS7320-1974 (Specification for concrete slump test apparatus)

[12] IS2386(Part 1)-1963 (Methods of test for aggregates for concrete)

[13] IS2386(Part 3)-1963 (Methods of test for aggregates for concrete) 